\title{
Pressure and angle of the seed-fertilizer drill press wheel on corn emergence
}

\author{
Dailson Dugato ${ }^{1} \&$ Marcos A. Z. Palma ${ }^{1}$ \\ ${ }^{1}$ Universidade Federal da Fronteira Sul/Unidade Acadêmica de Agronomia/Campus Cerro Largo. Cerro Largo. RS. E-mail: dailsondugatto@yahoo.com.br - \\ ORCID: 0000-0001-6015-9038; marcos.palma@uffs.edu.br (Corresponding author) - ORCID: 0000-0002-9826-4295
}

\section{Key words:}

no-till

mobilized soil area

seed furrow

\begin{abstract}
A B S T R A C T
In precision seed-fertilizer drills, the soil compaction mechanism is responsible for closing the furrow, pressing the soil over the seed. Among the available models, the most used is the V-type wheel system, with several options to regulate the wheel opening angle and pressure exerted on the soil. This study was carried out in the experimental area of the Federal University of Fronteira Sul - Campus Cerro Largo, in an clayey Red Latosol. Parameters related to corn emergence and the seedbed characteristics were evaluated at different regulations of opening angle and pressure of the compaction mechanism. The results indicate that mechanism regulations had no influence on emergence speed, emergence speed index and population of corn plants, under the studied conditions. However, the treatment with highest load and parallel alignment of the wheels caused lower values of elevated area and swelling. Treatments with $15^{\circ}$ opening angle caused accumulation of soil in the center of the row, affecting the elevation height.
\end{abstract}

\section{Palavras-chave:}

semeadura direta área de solo mobilizada sulco de semeadura

\section{Pressão e ângulo da roda compactadora de semeadora adubadora na emergência do milho}

\section{R E S U M O}

Em semeadoras adubadoras de precisão, o mecanismo de adensamento do solo é responsável pelo fechamento do sulco, pressionando o solo sobre a semente. Entre os modelos disponíveis, o mais utilizado é o sistema de rodas em "V", com algumas opções de regulagens de ângulo de abertura das rodas e da pressão exercida sobre o solo. O presente trabalho foi realizado na área experimental da Universidade Federal da Fronteira Sul (UFFS) - Campus Cerro Largo, em um Latossolo Vermelho de textura argilosa. Foram avaliados os parâmetros relacionados à emergência de plantas de milho e às características do leito de semeadura em diferentes configurações de ângulo e pressão do mecanismo de adensamento. Os resultados indicam que as configurações de regulagem do mecanismo não apresentaram influência sobre a velocidade de emergência, índice de velocidade de emergência e população de plantas do milho. No entanto, o tratamento com maior carga e alinhamento paralelo das rodas apresentou menores valores de área de elevação e empolamento. Os tratamentos com ângulo de abertura de $15^{\circ}$ apresentaram um acúmulo de solo no centro da linha, interferindo na altura de elevação. 


\section{INTRODUCTION}

Costs associated with soil tillage operations and the importance of conservation systems have caused farmers to adopt the direct seeding system, particularly in areas with risk of erosion (Conceição et al., 2016). In this cultivation system, the seed-fertilizer drill is responsible for opening the furrow, metering and depositing fertilizers and seeds, and then closing the furrow. To perform such operation, the recommended speed is up to $1.39 \mathrm{~m} \mathrm{~s}^{-1}$, because higher speeds lead to higher number of gaps in seed placement (Jasper et al., 2011; Bottega et al., 2014; Macedo et al., 2016), and precision mechanical meters are used. Besides the speed, factors such as type of meter (Dias et al., 2014) and conductor tube (Carpes et al., 2017) interfere with seed placement.

Press wheels perform the function of pressing the soil laterally to the seeds, causing the layer in the center of the row to be less dense, thus reducing the effort needed for epicotyl emergence. Currently, most seeders are equipped with V-type furrow-closing mechanisms, with regulations of opening angle and compaction pressure in most press wheels.

Studies conducted by Prado et al. (2002), evaluating different levels of seedbed compaction on the corn crop, indicated that as soil compression increases there is a higher emergence speed index and vigor of the seedlings, applying a force of up to $15 \mathrm{kgf}$ through the press wheel. According to Smucker \& Erickson (1989), soil compaction on the seedbed has beneficial effects attributed to the enhanced seed-soil contact, which favors the transfer of water and nutrients.

Through the modelling of soil and seed behavior by the Discrete Element Method (DEM), Zhou et al. (2014) observed that more compacted soils require higher pressure through the press wheel to increment the number of contacts and contact area between seed and soil. Soil compaction, besides being able to change corn seed germination, also modifies the growth of its shoots and roots according to Labegalini et al. (2016).

Thus, this study aimed to evaluate emergence speed, emergence speed index and population of corn plants, as a function of the regulations of pressure and opening angle of press wheels. In addition, seedbed characteristics, such as mobilized soil area, elevated soil area, elevation height in the center of the row and swelling were also evaluated.

\section{Material AND Methods}

The study was carried out in the experimental area of the Federal University of Fronteira Sul (UFFS), campus of Cerro Largo - RS, Brazil ( $\left.28^{\circ} 8^{\prime} 29^{\prime \prime} \mathrm{S} ; 54^{\circ} 45^{\prime} 35^{\prime \prime} \mathrm{W}\right)$. The soil is classified as typic dystroferric Red Latosol with clayey texture (Streck et al., 2008).

Treatments resulted from the combination of two regulations of the opening angle and pressure exerted by the wheels of the soil compaction mechanism on the seed row, evaluating: two regulations of opening angle $\left(0^{\circ}\right.$ and $\left.15^{\circ}\right)$ and two regulations of compaction pressure, corresponding to the static loads of 176 and $372 \mathrm{~N}$. A control treatment was also considered, in which the wheels were removed from the seed-fertilizer drill to avoid interference with the seed furrow.
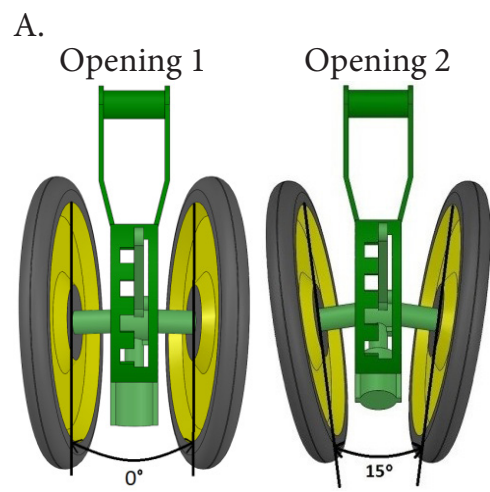

B.

Figure 1. Regulations of opening angle used in the experiment (A). Side view of the press wheel (B)

The opening angle between the wheels was evaluated parallel to the soil at the axle height, according to Figure 1A. Pressure was regulated by a lever subjected to the action of a traction spring (Figure 1B).

The experiment was set up in a randomized block design (RBD) with 5 treatments and 4 replicates ( 4 blocks), totaling 20 plots. Each plot comprised 5 seed rows with $7 \mathrm{~m}$ length and $0.5 \mathrm{~m}$ spacing between rows.

Corn was sown using an agricultural tractor (New Holland, TL 75 model with auxiliary front wheel drive system - TDA, and $57-\mathrm{kW}$ power) attached to a precision seed-fertilizer drill (KF Compacta ${ }^{\circ}$. The seed-fertilizer drill traveled at speed of $1.39 \mathrm{~m} \mathrm{~s}^{-1}$ distributing 3.3 seeds per linear meter in order to achieve a population of 65,000 plants per hectare of the super early hybrid Dekalb $240^{\circ}$. Fertilization was performed by applying a formulated fertilizer (NPK) in the seed row and urea as top-dressing, as indicated by the Rede Oficial de Laboratórios de Análise de Solos (ROLAS, 2004), based on soil chemical analysis.

For soil characterization, density and moisture content were evaluated according to the methodology proposed by EMBRAPA (2011). Eight undisturbed samples were collected in the experimental area, in the layers of 0-0.10 and 0.10-0.20 m.

Evaluations were carried out for parameters related to seedling emergence (emergence speed, emergence speed index and final plant population) and seed furrow (elevated soil area, mobilized soil area, central elevation height and swelling).

Emergence speed index was evaluated following the methodology described by Maguire (1962), using Eq. 1:

$$
\mathrm{ESI}=\left(\frac{\mathrm{G} 1}{\mathrm{~N} 1}\right)+\left(\frac{\mathrm{G} 2}{\mathrm{~N} 2}\right)+\cdots\left(\frac{\mathrm{Gn}}{\mathrm{Nn}}\right)
$$

where:

ESI - emergence speed index;

G - number of normal seedlings computed in the counts; and,

$\mathrm{N}$ - number of days after sowing in each count.

Emergence speed was evaluated according to the methodology of Edmond \& Drapala (1958), as shown in Eq. 2.

$$
\mathrm{ES}=\left[\frac{(\mathrm{N} 1 \times \mathrm{G} 1)+(\mathrm{N} 2 \times \mathrm{G} 2)+\ldots+(\mathrm{Nn} \times \mathrm{Gn})}{(\mathrm{G} 1+\mathrm{G} 2+\ldots+\mathrm{Gn})}\right]
$$


where:

ES - emergence speed;

G - number of normal seedlings computed in the counts; and,

$\mathrm{N}$ - number of days after sowing in each count.

Seedlings were daily counted from the first ones emerged at 9 days after sowing until stabilization at 30 days after sowing. Only normal seedlings were considered (Brasil, 2009).

The seedbed was evaluated using a profilometer with $0.005 \mathrm{~m}$ accuracy, composed of a $1.2 \mathrm{~m}$ high, $1 \mathrm{~m}$ wide metal structure. In the instrument, the row of 0.0035-m-diameter cylindrical fiber glass rods was arranged perpendicularly to the soil, transverse to the seed row, recording the soil profile. The data in the device were read through digital photographs, obtained with a 5-Mp camera fixed on a tripod positioned at a distance of $1.5 \mathrm{~m}$ in front of the device. Then, the photographs were transferred to an computer-assisted drawing software to digitize the data.

To determine the variation of soil surface profile, the device was installed always at the same height and site, repeating 3 times the evaluations in each plot. The first measurement corresponds to the natural surface, before the machine passed. After the test, the elevation profile above the seed row and the furrow bottom profile were obtained, by carefully removing the soil mobilized by the rod.

The elevated soil area, above the natural surface, indicates the amount of soil exposed during the seeding operation. Mobilized soil area results from the difference between natural soil surface and furrow bottom profile, removing the mobilized soil above it. Soil swelling was determined by the ratio between total elevated area and mobilized area (Eq. 3), following the methodology proposed by Gamero \& Benez (1990).

$$
\mathrm{SS}=\frac{\mathrm{Ae}}{\mathrm{Am}} \times 100
$$

where:

SS - soil swelling (\%);

Ae - elevated area $\left(\mathrm{m}^{2}\right)$; and,

Am - mobilized area $\left(\mathrm{m}^{2}\right)$.

To obtain a parameter that indicates possible alterations in seed placement depth, the elevation height of the central row was evaluated, which corresponds to the difference of height between the natural surface of the terrain and the elevation surface in the center of the row.

The mean elevation profile of each treatment was determined using the computer-assisted drawing software and, after digitizing the lines corresponding to the elevation profiles and natural surface, a sequence of vertical lines spaced by $0.01 \mathrm{~m}$ was created. These lines were cut at the ends, leaving only the line segments between the natural profile and elevation profile (Figure 2).

The length of each vertical line indicates the height of elevated soil in relation to the natural surface (elevation height). A spreadsheet editing program was used to obtain the mean length of each line between the 4 replicates, resulting in a graph which represents the mean elevation of each treatment.

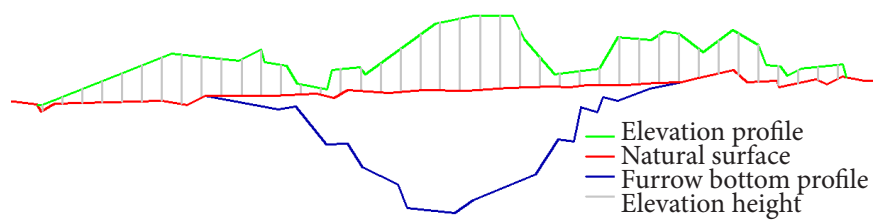

Figure 2. Scheme of the profiles evaluated

\section{Results AND Discussion}

The soil, at the moment of sowing, had moisture content of $0.25 \mathrm{~kg} \mathrm{~kg}^{-1}$ in the surface layer $(0-0.10 \mathrm{~m})$. In the $0.10-0.20 \mathrm{~m}$ layer, the moisture content was $0.28 \mathrm{~kg} \mathrm{~kg}^{-1}$, differing from the surface layer by Scott-Knott test at 0.05 probability level. Density was equal to $1410 \mathrm{~kg} \mathrm{~m}^{-3}$ in the surface layer and to $1400 \mathrm{~kg} \mathrm{~m}^{-3}$ in the underlying layer $(0.10-0.20 \mathrm{~m})$, which did not differ statistically.

Emergence speed, emergence speed index and plant population were not significantly different between treatments, as shown in Table 1.

The results indicate that the mechanism regulations had no influence on corn emergence. Even the use of the component is not significant under the evaluated conditions, because the control (without the action of the mechanism) did not differ from the other treatments. This can be justified by the adequate rainfall along the emergence period. According to the data of INMET (2015), the rainfall in September was equal to $115 \mathrm{~mm}$ and the first rain occurred already on the second day after sowing.

These results are consistent with those found by Prado et al. (2002), who observed no difference emergence speed at different sowing depths from 0.03 to $0.07 \mathrm{~m}$ in experiment with water supplementation for the corn crop. This can be explained by the hypogeal germination, characteristic of the crop, which moves a smaller amount of soil to emerge. Thus, the possible differences of depth caused by the action of the mechanism are not sufficient to interfere with the emergence under adequate moisture conditions. However, Prado et al. (2002) and Weirich Neto \& Lopes (2012) found an increment in corn emergence speed index, with the increase in soil compaction above the seed, especially for sowing at lower depth.

Similar results were found by Reis et al. (2006), who observed differences in corn emergence working with moisture contents of $0.22,0.28$, and $0.34 \mathrm{~kg} \mathrm{~kg}^{-1}$ and two types of furrowers, referred to as stub runner and double disc-type. However, Trogello et al. (2013) observed that cultivation systems which cut the straw into smaller pieces caused better emergence speed indices. The authors point out that straw cutting allowed higher incidence of light and greater homogeneity of temperature and

Table 1. Emergence speed (ES), emergence speed index (ESI) and plant population per hectare as a function of the treatments

\begin{tabular}{lccc}
\hline Treatment & ES & ESI & plants ha $^{-1}$ \\
T1 & $17.08 \mathrm{a}$ & $35.65 \mathrm{a}$ & $63,857 \mathrm{a}$ \\
T2 & $16.78 \mathrm{a}$ & $36.58 \mathrm{a}$ & $62,285 \mathrm{a}$ \\
T3 & $17.36 \mathrm{a}$ & $33.25 \mathrm{a}$ & $62,857 \mathrm{a}$ \\
T4 & $17.73 \mathrm{a}$ & $30.37 \mathrm{a}$ & $62,857 \mathrm{a}$ \\
T5 (control) & $17.42 \mathrm{a}$ & $32.01 \mathrm{a}$ & $61,714 \mathrm{a}$ \\
CV (\%) & $\mathrm{CV} \%=3.28$ & $\mathrm{CV} \%=12.37$ & $\mathrm{CV} \%=1.60$ \\
\hline
\end{tabular}

Results followed by the same letter do not differ by Scott-Knott test at 0.05 probability level 
moisture along the area. These characteristics can lead to better microclimate conditions for crop emergence.

Furthermore, Modolo et al. (2010) worked with bean sowing and found no differences in emergence speed and emergence speed index, when the pressure of the press wheels was altered. The parameters were affected only when sowing depth was changed.

The measurements of the parameters related to the profile produced in each treatment are organized in Table 2.

Elevated soil area was larger in the control; the treatments T1, T3 and T4 differed from one another, whereas T2 showed the lowest result. Thus, it is possible to claim that the mechanism contributes to reducing the soil volume deposited above the natural surface. Based on the mean elevation profile of the treatment T2 in Figure 3, it is possible to conclude that this occurs because of the higher pressure of the mechanism on the row, even causing depressions on furrow sides, where the press wheels passed.

Elevation height in the center of the row was lower in T2 and T5. In T2, the result can be related to the higher pressure of the wheels on the soil. It can be noted that the parallel alignment of the wheels causes lower central elevation, differing from T4, which caused higher soil accumulation in the center of the row with the same pressure, but $15^{\circ}$ angle. In the control (T5), the mean value of central elevation was negative, which means that the seed furrow remained open after the double disc passed, with the central elevation height below the natural soil surface, as can be observed in the mean elevation profile of T5 in Figure 3 and through the comparison between Figures $4 \mathrm{~A}$ (T3) and B (T5).

Mobilized soil area did not differ between treatments, which was already expected because this parameter is an effect of the action of the furrower, which turns the soil before the press wheels pass, and is not interfered by the mechanism evaluated. Silva et al. (2012), evaluating the mobilized soil area in direct seeding, concluded that the increment of load, applied on the furrowers, increases the mobilized soil area.

Soil swelling was higher in the control, due to the formation of air pockets between the aggregates, a result that emphasizes the importance of using the mechanism. The treatments T1, T3 and T4 did not differ, whereas T2 showed the lowest result due to the higher load exerted on the row and the parallel position between the wheels. Lower swelling in T2 is consistent with the result of the elevated soil area, which was lower in this treatment, demonstrating the higher soil compaction caused by this mechanism regulation.

Nevertheless, the results indicate that the mechanism interferes with the seed row characteristics and the regulations tested led to different elevation profiles. Despite not having direct influence on corn emergence, it should be highlighted

A.

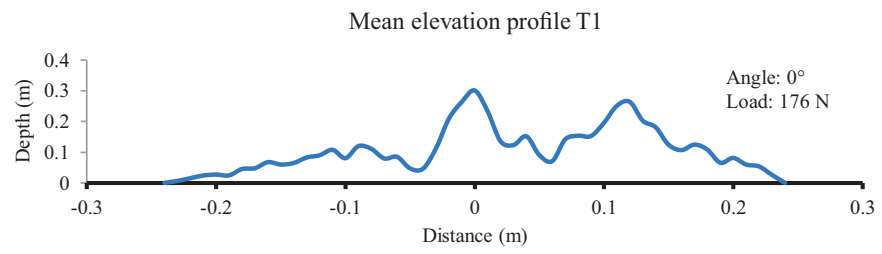

B.

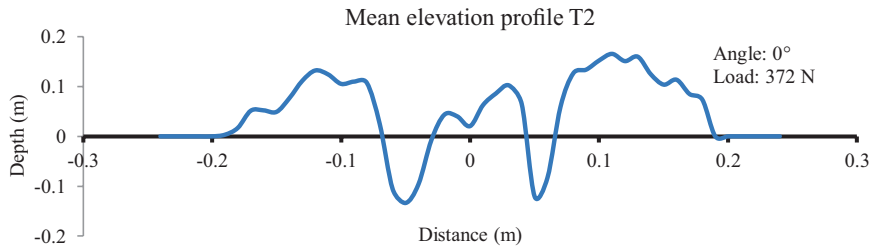

C.

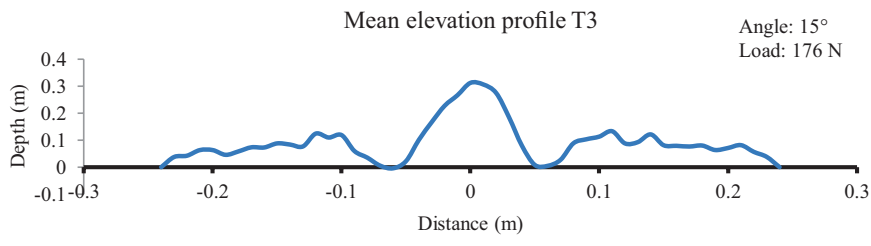

D.

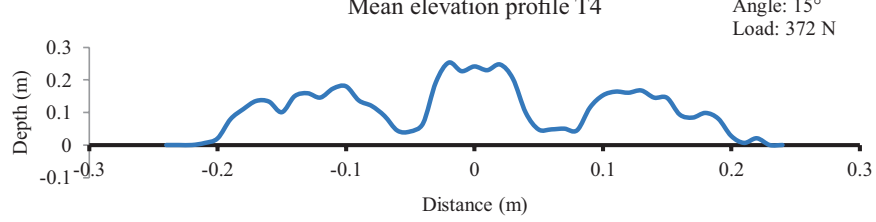

E.

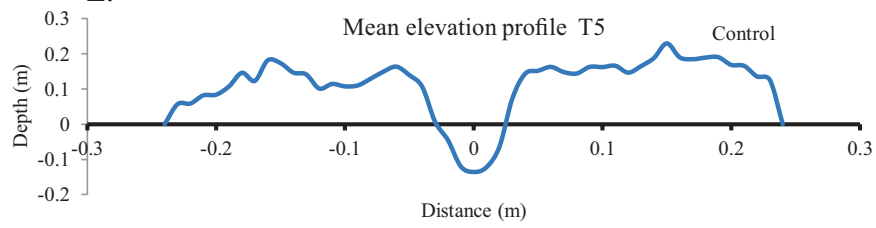

Figure 3. Mean elevation profile of the treatments

A.

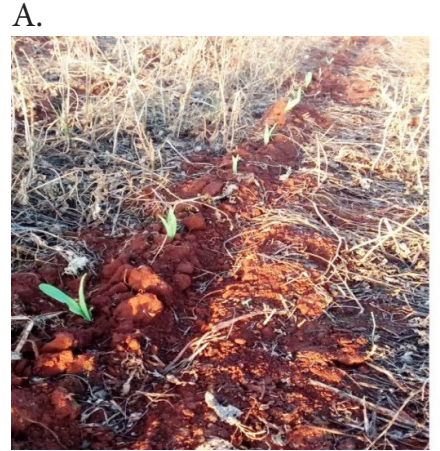

Figure 4. Emergence of co Control T5 (B)

that the results are intrinsic to the condition of soil and moisture occurred in the experiment.

Table 2. Results related to seed row profile as a function of the treatments

\begin{tabular}{ccccc}
\hline Treatments & $\begin{array}{c}\text { Elevated area } \\
\left(\mathbf{m}^{2}\right)\end{array}$ & $\begin{array}{c}\text { Elevation height in the center } \\
\text { of the row }(\mathbf{m})\end{array}$ & $\begin{array}{c}\text { Mobilized soil area } \\
\left(\mathbf{m}^{2}\right)\end{array}$ & $\begin{array}{c}\text { Swelling } \\
(\%)\end{array}$ \\
T1 & $0.0058 \mathrm{~b}$ & $0.0211 \mathrm{a}$ & $0.0083 \mathrm{a}$ & $70 \mathrm{~b}$ \\
T2 & $0.0029 \mathrm{C}$ & $0.0200 \mathrm{~b}$ & $0.0066 \mathrm{a}$ & $46 \mathrm{c}$ \\
T3 & $0.0061 \mathrm{~b}$ & $0.0311 \mathrm{a}$ & $0.0084 \mathrm{a}$ & $76 \mathrm{~b}$ \\
T4 & $0.0059 \mathrm{~b}$ & $0.0241 \mathrm{a}$ & $0.0074 \mathrm{a}$ & $81 \mathrm{~b}$ \\
T5 & $0.0100 \mathrm{a}$ & $-0.0137 \mathrm{~b}$ & $0.0079 \mathrm{a}$ & $128 \mathrm{a}$ \\
CV & $14.46 \%$ & 12.21 & $12.40 \%$ & $21.59 \%$ \\
\hline
\end{tabular}

Results followed by the same letter do not differ by Scott-Knott at 0.05 probability level 
According to Mialhe (2012), the lack of soil-seed contact can compromise emergence, especially in situations of water deficit. Therefore, the use of press wheels is recommended because, in the control (T5), the furrow remained open, as can be observed in Figure 4B.

Opening angle of $15^{\circ}$ between wheels helps close the furrow; however, attention should be paid to the accumulation of soil on the row, which may cause higher resistance to seedling emergence. Thus, the opening angle can be used without the need for sweeping wheels and covering mechanisms, which have great importance in burying the seed deeper in the soil, according to Brandelero et al. (2014).

\section{Conclusions}

1. The configurations of pressure and opening angle of the seed row compaction mechanism do not interfere with emergence speed, emergence speed index and population of corn plants in clayey Red Latosol in situations of adequate rainfall.

2. The press wheel evaluated has beneficial effect on the transverse profile of the seed row, promoting the closing of the furrow.

3. Using a $15^{\circ}$ opening angle results in accumulation of soil in the center of the row, altering the sowing depth.

4. Using a $372 \mathrm{~N}$ load and parallel alignment between wheels led to lower values of elevated area, height in the center of the row and swelling.

\section{Literature Cited}

Bottega, E. L.; Braido, R.; Piazzetta, H. von L.; Oliveira Neto, A. M. de; Guerra, N.; Efeitos da profundidade e velocidade de semeadura na implantação da cultura do milho. Pesquisa Agropecuária Pernambucana, v.19, p.74-78, 2014. https://doi.org/10.12661/ pap.2014.011

Brandelero, E. M.; Araujo, A. G. de; Ralisch, R. Mobilização do solo e profundidade de semeadura por diferentes mecanismos para o manejo do sulco de semeadura em uma semeadora direta. Engenharia Agrícola, v.34, p.254-262, 2014. https://doi. org/10.1590/S0100-69162014000200008

Brasil. Ministério da Agricultura, Pecuária e Abastecimento Secretaria de Defesa Agropecuária. Regras para análise de sementes. Brasília: MAPA/ACS, 2009. 395p.

Carpes, D. P.; Alonço, A. dos S.; Rossato, F. P.; Veit, A. A.; Souza, L. B. de; Francetto, T. R. Effect of different conductor tubes on the longitudinal distribution of corn seeds. Revista Brasileira de Engenharia Agrícola e Ambiental, v.21, p.657-662, 2017. https:// doi.org/10.1590/1807-1929/agriambi.v21n9p657-662

Conceição, L. A.; Barreiro, P.; Dias, S.; Garrido, M.; Valero, C.; Silva, J. R. M. da. A partial study of vertical distribution of conventional no-till seeders and spatial variability of seed depth placement of maize in the Alentejo region, Portugal. Precision Agriculture, v.17, p.36-52, 2016. https://doi.org/10.1007/s11119-015-9405-X

Dias, V. de O.; Alonço, A. dos S.; Carpes, D. P.; Veit, A. A.; Souza, L. B. de. Velocidade periférica do disco em mecanismos dosadores de sementes de milho e soja. Ciência Rural, v.44, p.1973-1979, 2014. https://doi.org/10.1590/0103-8478cr20121201

Edmond, J. B.; Drapala, W. J. The effects of temperature, sand and soil, and acetone on germination of okra seeds. Proceedings of American Society of Horticultural Science, v.71, p.428-434, 1958.
EMBRAPA - Empresa Brasileira de Pesquisa Agropecuária - Centro Nacional de Pesquisas de Solos. Manual de métodos de análises de solos. 2.ed. Rio de Janeiro: Embrapa Solos, 2011. 230p.

Gamero, C. A.; Benez, S. H. Avaliação da condição do solo após a operação de preparo. In: Ciclo de Estudos Sobre Mecanização Agrícola, 4, 1989, Jundiaí. Anais... Campinas: Fundação Cargill, 1990. p.12-21.

INMET - Instituto Nacional de Meteorologia. Dados meteorológicos, estação de São Luiz Gonzaga. Available on: <http://www.inmet. gov.br/portal/index.php? $r=$ estacoes/estacoesConvencionais $>$. Access on: Nov. 2015.

Jasper, R.; Jasper, M.; Assumpção, P. S. M.; Rocil, J.; Garcia, L. C. Velocidade de semeadura da soja. Engenharia Agrícola, v.31, p.102110, 2011. https://doi.org/10.1590/S0100-69162011000100010

Labegalini, N. S.; Damião, F. N.; Andrade, L. Desenvolvimento da cultura do milho sob efeitos de diferentes profundidades de compactação do solo. Revista de Agricultura Neotropical, v.3, p.7-11, 2016.

Macedo, D. X. S.; Nicolau, F. E. de A.; Nascimento, H. C. F. do; Costa, E.; Chioderoli, C. A.; Loureiro, D. R. Operational performance of a tractor-seeder according to the velocity and working depth. Revista Brasileira de Engenharia Agrícola e Ambiental, v.20, p.280-285, 2016. https://doi.org/10.1590/1807-1929/agriambi.v20n3p280-285

Maguire, J. D. Speed of germination aid in selection and evaluation for seedling emergence and vigor. Crop Science, v.2, p.176-177, 1962. https://doi.org/10.2135/cropsci1962.0011183X000200020033x

Mialhe, L. G. Máquinas agrícolas para plantio. Campinas: Millennium, 2012. 623p.

Modolo, A. J.; Trogello, E. N.; Luis, F. A.; Haroldo, C.; Silveira, J. C. M. da; Dambrós, M. P. Efeito de cargas aplicadas e profundidades de semeadura no desenvolvimento da cultura do feijão em sistema plantio direto. Ciência \& Agrotecnologia, v.34, p.739-745, 2010. https://doi.org/10.1590/S1413-70542010000300029

Prado, R. M.; Coan, O.; Villar, M. L. P. Compressão do solo e profundidade de semeadura na emergência e no crescimento inicial da cultura do milho (Zea Mays L.). Revista Científica Eletrônica de Agronomia, v.2, p.1-6, 2002.

Reis, E. F. dos; Schaefer, C. E. G. R.; Fernandes, H. C.; Naime, J. de M.; Araújo, E. F. Densidade do solo no ambiente solo-semente e velocidade de emergência em sistema de semeadura de milho. Revista Brasileira de Ciência do Solo, v.30, p.777-785, 2006. https://doi.org/10.1590/S0100-06832006000500003

ROLAS - Rede Oficial de Laboratórios de Análise de Solo e de Tecido Vegetal. Manual de adubação e calagem para os estados do Rio Grande do Sul e Santa Catarina. Porto Alegre: ROLAS, 2004. 400p.

Silva, P. R. A.; Benez, S. H.; Jasper, S. P.; Seki, A. S.; Masiero, F. C.; Riquetti, N. B. Semeadora-adubadora: Mecanismos de corte de palha e cargas verticais aplicadas. Revista Brasileira de Engenharia Agrícola e Ambiental, v.16, p.1367-1373, 2012. http://dx.doi. org/10.1590/S1415-43662012001200015

Smucker, A. J. M.; Erickson, A. E. Tillage and compactive modifications of gaseous flow and soil aeration. Mechanics related process in structured agricultural soils. NATO Applied Sciences, v.172, p.205-221, 1989.

Streck, E. V.; Kämpf, N.; Dalmolin, R. S. D.; Klamt, E.; Nascimento, P. C. do; Schneider, P.; Giasson, E.; Pinto, L. F. S. Solos do Rio Grande do Sul. 2.ed. rev. ampl. Porto Alegre: EMATER, 2008. 222p.

Trogello, E.; Modolo, A. J.; Scarsi, M. S.; Silva, C. L. da; Adami, P. F.; Dallacort, R. Manejos de cobertura vegetal e velocidades de operação em condições de semeadura e produtividade de milho. Revista Brasileira de Engenharia Agrícola e Ambiental, v.17, p.796802, 2013. https://doi.org/10.1590/S1415-43662013000700015 
Weirich Neto, P. H.; Lopes, A. R. C. Emergence of corn according to the sowing depth of the seed and loads on press wheels. Engenharia Agrícola, v.32, p.326-332, 2012. https://doi.org/10.1590/S010069162012000200012
Zhou, H.; Chen, Y.; Sadek, M. A. Modelling of soil-seed contact using the Discrete Element Method (DEM). Biosystems Engineering, v.121, p.56-66, 2014. https://doi.org/10.1016/j. biosystemseng.2014.02.006 